\title{
Social defeat stimulates local glucocorticoid regeneration in lymphoid organs
}

\author{
Peter Ergang ${ }^{1}$, Anna Mikulecká ${ }^{1}$, Martin Vodička ${ }^{1,2}$, Karla Vagnerová ${ }^{1}$, Ivan Mikšík ${ }^{1}$ and Jiří Pácha ${ }^{1,2}$ \\ ${ }^{1}$ Institute of Physiology, Academy of Sciences of the Czech Republic, Prague, Czech Republic \\ 2Department of Physiology, Faculty of Science, Charles University, Prague, Czech Republic \\ Correspondence should be addressed to J Pácha: pacha@biomed.cas.cz
}

\begin{abstract}
Stress is an important risk factors for human diseases. It activates the hypothalamicpituitary-adrenal (HPA) axis and increases plasma glucocorticoids, which are powerful regulators of immune system. The response of the target cells to glucocorticoids depends not only on the plasma concentrations of cortisol and corticosterone but also on their local metabolism. This metabolism is catalyzed by $11 \beta$-hydroxysteroid dehydrogenases type 1 and 2, which interconvert glucocorticoid hormones cortisol and corticosterone and their 11-oxo metabolites cortisone and 11-dehydrocorticosterone. The goal of this study was to determine whether stress modulates glucocorticoid metabolism within lymphoid organs - the structures where immune cells undergo development and activation. Using the resident-intruder paradigm, we studied the effect of social stress on glucocorticoid metabolism in primary and secondary lymphoid organs of Fisher 344 (F344) and Lewis (LEW) rats, which exhibit marked differences in their HPA axis response to social stressors and inflammation. We show that repeated social defeat increased the regeneration of corticosterone from 11-dehydrocorticosterone in the thymus, spleen and mesenteric lymphatic nodes (MLN). Compared with the F344 strain, LEW rats showed higher corticosterone regeneration in splenocytes of unstressed rats and in thymic and MLN mobile cells after stress but corticosterone regeneration in the stroma of all lymphoid organs was similar in both strains. Inactivation of corticosterone to 11-dehydrocorticosterone was found only in the stroma of lymphoid organs but not in mobile lymphoid cells and was not upregulated by stress. Together, our findings demonstrate the tissue- and strain-dependent regeneration of glucocorticoids following social stress.
\end{abstract}

\author{
Key Words \\ - glucocorticoid metabolism \\ - lymphoid organs \\ - Lewis rats \\ - Fisher 344 rats \\ - resident-intruder paradigm \\ - social stress
}

\section{Introduction}

Stress is a ubiquitous condition that affects both people and animals. It initiates a series of events, culminating in the activation of the hypothalamic-pituitaryadrenal (HPA) axis and sympathetic nervous system (SNS), including the sympathetic-adrenal-medullary axis, which subsequently release glucocorticoids and catecholamines, respectively. The HPA and SNS axes are the two major pathways through which stress is able to modulate immune functions depending on the nature, intensity and duration of stress (1). Chronic stress can stimulate immunosuppression and increase susceptibility to diseases (2) or can enhance immune reactivity and induce insensitivity to glucocorticoids, which prevents glucocorticoid-induced suppression of inflammation (3). Acute stress increases transiently plasma glucocorticoids, whereas chronic stress is associated with a chronic elevation of circulating glucocorticoids (4).
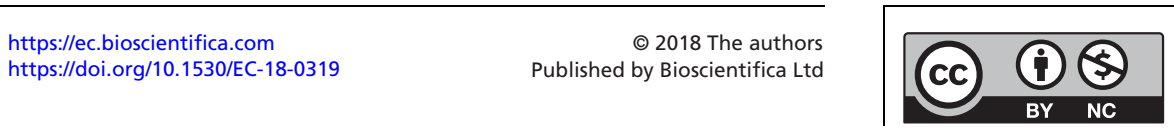
The response of the target cells to glucocorticoids does not merely depend on the level of the free hormone, activity of multidrug resistance efflux pumps and density of glucocorticoid receptors in target cells but also on the prereceptor metabolism of glucocorticoids, which is catalyzed by two enzymes, 11 $\beta$-hydroxysteroid dehydrogenase type 1 (11HSD1) and type 2 (11HSD2). $11 \mathrm{HSD} 2$ is an enzyme that catalyzes the oxidations of cortisol and corticosterone to the inactive cortisone and 11-dehydrocorticosterone, reducing the local glucocorticoid signals. In contrast, 11HSD1 converts biologically inactive 11-oxo steroids (cortisone and 11-dehydrocorticosterone) to cortisol and corticosterone, amplifying the cellular glucocorticoid action (5). 11HSD1 is expressed in many organs and tissues, including lymphoid organs and immune cells $(6,7,8,9)$. 11HSD2 is predominantly expressed in mineralocorticoid target tissues, but moderate levels of 11HSD2 have also been found in lymphoid organs (10). Stressful situations have been shown to modulate the expression of 11HSD1 in the brain and some peripheral organs, but the results are contradictory $(11,12,13,14,15$, 16). For example, chronic social stress increased 11HSD1 expression in the rat hippocampus (12) but decreased it in the hippocampus of tree shrews (13) and in the rat testes (15). Similarly, chronic restraint stress upregulated 11HSD1 in the liver (11) but not in the thymus (14).

Given the fact that chronic stress is associated with an increased risk of many diseases including autoimmune disorders $(17,18)$, these effects are often attributed to the dysregulation of the HPA axis $(1,17)$ and the activity of lymphocytes and other leukocytes is potently modulated by glucocorticoids $(19,20,21)$, the goal of this study was to determine (i) whether social stress influences the local metabolism of glucocorticoids in primary and secondary lymphoid organs, i.e. in the structures where immune cells undergo development and activation and (ii) whether there is any strain predisposition for the effect of stress on the lymphoid organs. To study these questions, we used two inbred rat strains, Fisher 344 (F344) and Lewis (LEW) rats, which represent two ends of a spectrum of HPA axis responsiveness to stress (22, 23) and vulnerability to immune diseases (24). The F344 strain has been classically used as a model of HPA axis hyperactivity and hyperreactivity to stress, whereas the LEW strain shows vulnerability to immune diseases due to a hypoactive and hyporeactive HPA axis (22). To induce stress, the animals were submitted to repeated social defeat, which is the result of intraspecific confrontation between male rats. This model provides a relevant tool to study stress response features, as well as differences in the vulnerability and resilience to stress and exposing the test animal to a dominant and aggressive counterpart for a known period of time is thought to mimic psychological stress in humans (25).

\section{Materials and methods}

\section{Animals and social defeat paradigm}

The animals used in the present study were male F344 and LEW rats, aged 65 days, that were purchased from Charles River, Germany. Animals were kept in groups of three to four in standard transparent cages in a temperature-controlled room $\left(23 \pm 1^{\circ} \mathrm{C}\right)$ on a $12 / 12$-h light/darkness cycle with ad libitum access to food and water, and they were left for 3 weeks to acclimatize before any experimental procedure. Additionally, Long Evans retired male breeders (Institute of Physiology, Academy of Science, Prague) were chosen for consistent aggressive behavior. In contrast to the experimental animals, the Long Evans rats were housed individually. The F344 and LEW animals were randomly assigned to four groups, each consisted of eight rats, as follows: (1) control F344 rats, (2) defeated F344 rats, (3) control LEW rats and (4) defeated LEW rats. Control rats were placed in an adjacent room under the lighting conditions mention above and were then left undisturbed in their home cages.

To stress the animals, we used a slight modification of the resident-intruder paradigm validated by other authors (26). The resident-intruder test consisted of placing a smaller experimental rat (intruder) in the home cage of a larger and aggressive conspecific rat (resident), which defended its territory and defeated the intruder. The experimental rats were confronted with a resident male for $15 \mathrm{~min}$ each in the home cage of a Long Evans rat. The paradigm was repeated once daily for ten consecutive days, and each intruder was exposed to a novel resident to prevent habituation to the resident. No intruder was wounded by the residents during the repeated confrontations. The male rats were used for this study because they are more sensitive to social defeat than females (27).

The experiments were performed in the morning (between 09:00 and 12:00h), and all animal procedures were performed in accordance with Institutional Animal Care and Use Committee regulations.

\section{Tissue collection and processing}

Control rats and the rats after the last social interaction session were immediately anesthetized with isoflurane

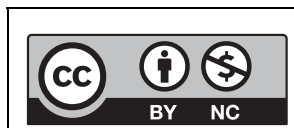

This work is licensed under a Creative Commons Attribution-NonCommercial 4.0 International License. 
and blood was collected by cardiac puncture. Then, the rats were decapitated, and the pituitary, thymus, spleen and mesenteric lymphatic nodes (MLNs) were quickly collected, cleaned of fat and connective tissues and weighted. The harvested thymus, spleen and MLN were used immediately for preparation of cell suspension of mobile cells and stroma, as described previously (6). Briefly, the lymphoid cell suspensions were prepared in RPMI 1640 medium by pressing the organs with a syringe plunger, filtering the suspension through nylon cell strainer (mesh size $45 \mu \mathrm{m}$ ) and washing the cell suspensions and remaining stroma twice in RPMI 1640 before measurement of the 11HSD activity. Erythrocytes were depleted from the spleen cell suspension by lysis in ACK lysis buffer.

\section{Measurement of 11HSD activity}

Isolated cells and stroma minced into fine pieces were used immediately to measure 11HSD1 and 11HSD2 activities. The 11-reductase activity assay for 11HSD1 was performed by measuring corticosterone produced from 11-dehydrocorticosterone and 11-oxidase assay for 11HSD2 was done by measuring the conversion of corticosterone to 11-dehydrocorticosterone as described previously (6). In brief, isolated cells and stroma were incubated in culture media consisting of RPMI 1640 supplemented with 5\% charcoal-stripped fetal bovine serum (Biochrom $\mathrm{GmbH}$ ), $100 \mathrm{IU} / \mathrm{mL}$ penicillin, $10 \mu \mathrm{g} / \mathrm{mL}$ streptomycin, $0.3 \mathrm{mg} / \mathrm{L}$ L-glutamine and $4.5 \mathrm{~g} / \mathrm{L}$ glucose in the presence of $12.8 \mathrm{nM}\left[{ }^{3} \mathrm{H}\right] 11$-dehydrocorticosterone or $\left[{ }^{3} \mathrm{H}\right]$ corticosterone in an atmosphere of $5 \% \mathrm{CO}_{2}$ and $95 \% \mathrm{O}_{2}$ at $37^{\circ} \mathrm{C}$. $\left[{ }^{3} \mathrm{H}\right]$ Corticosterone was purchased from MP Biomedicals (Santa Anna, USA) and $\left[{ }^{3} \mathrm{H}\right] 11$ dehydrocorticosterone was synthesized 'in house' from $\left[{ }^{3} \mathrm{H}\right]$ corticosterone using kidney microsomes prepared from guinea pig. After $24 \mathrm{~h}$ of incubation, the samples were centrifuged, the pellets used for protein quantification using the BCA method and the steroids extracted from the supernatants using C18 reverse phase Sep-Pak cartridges (Phenomenex, USA). Pituitary 11HSD1 activity was measured in minced pituitary explants using the same tissue culture procedure as for lymphoid organs.

The extracted samples were evaporated to dryness under nitrogen at $40^{\circ} \mathrm{C}$, reconstituted in methanol and analyzed using HPLC as previously described $(28,29)$. The elution of radioactive steroids was detected using Radiomatic 150TR Flow Scintillation Analyzer (Canberra Packard, USA) and the identification of radiolabeled corticosterone and 11-dehydrocorticosterone peaks
(Supplementary Fig. 1, see section on supplementary data given at the end of this article) was performed by comparison with the elution profiles of the unlabeled steroid standards (Steraloids, Newport, RI, USA).

\section{Plasma corticosterone and ACTH determination}

The plasma corticosterone and ACTH concentrations were determined using commercially available radioimmunoassay (Corticosterone ${ }^{125} \mathrm{I}$ RIA, MP Biomedicals, Solon, OH, USA) and enzyme immunoassay (ACTH ELISA, MD Bioproducts, Eggs, Switzerland) kits, respectively. The samples for each assay were determined in a single run to prevent inter-assay variability according to the manufacturer's instructions. The sensitivity of the corticosterone and ACTH assays were $7.7 \mathrm{ng} / \mathrm{mL}$ and $0.22 \mathrm{pg} / \mathrm{mL}$, respectively.

\section{Statistical analysis}

The results are expressed as the means \pm s.E.M. All calculations were conducted in Statistica 6.1. (StatSoft Inc., Tulsa, OK, USA) using a two-way ANOVA for comparisons involving the effects of stress and strain. The independent variables were the treatment and strain, consisting of two levels, which were unstressed or stressed and F344 or LEW, respectively. Post hoc analyses were performed using Fisher's LSD test. Differences were considered significant at $P<0.05$.

\section{Results}

Effect of stress on weights of thymus, spleen and adrenal gland and on plasma levels of ACTH and corticosterone

Statistical analysis revealed a decreased body weight in repeatedly stressed LEW rats but control and stressed F344 rats had similar body weight not only on Day 1 but also on Day 10 (Table 1). Stress significantly increased the relative adrenal weight in F344 rats but not in LEW rats. No differences were observed in the spleen and thymus weights of stressed and unstressed animals of both strains.

Figure 1 shows plasma ACTH and corticosterone levels in unstressed and stressed F344 and LEW rats. A two-way ANOVA revealed a significant effect of stress $\left(F_{1,24}=16.17\right.$, $P<0.01)$ and strain $\left(F_{1,24}=11.11, P<0.01\right)$ on ACTH. As given in Fig. 1A, stress significantly increased ACTH level in F344 rats and had a nonsignificant tendency to increase ACTH level also in LEW rats $(P=0.067)$. Whereas the plasma
This work is licensed under a Creative Commons Attribution-NonCommercial 4.0 International License. 
Table 1 Effect of repeated social defeat on the body and organ weights.

\begin{tabular}{|c|c|c|c|c|}
\hline & \multicolumn{2}{|c|}{ F344 } & \multicolumn{2}{|c|}{ LEW } \\
\hline & Control & Defeat & Control & Defeat \\
\hline Body weight day 1 & $184 \pm 2$ & $188 \pm 2$ & $247 \pm 4$ & $244 \pm 4$ \\
\hline Body weight day 10 & $225 \pm 3$ & $224 \pm 3$ & $303 \pm 3$ & $283 \pm 2 * * *$ \\
\hline Thymus & $179 \pm 5$ & $171 \pm 6$ & $190 \pm 7$ & $172 \pm 5$ \\
\hline Spleen & $241 \pm 3$ & $239 \pm 2$ & $202 \pm 2^{\# \#}$ & $222 \pm 15$ \\
\hline Adrenal gland & $15 \pm 1$ & $22 \pm 2 *$ & $15 \pm 1$ & $17 \pm 0$ \\
\hline
\end{tabular}

Body weight is expressed in grams and organ weights in milligrams per $100 \mathrm{~g}$ of body weight (shown as mean \pm S.E.M., $n=6-7$ rats per group). Statistically

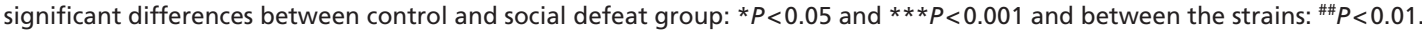

levels of ACTH in unstressed LEW and F344 rats were similar, ACTH levels in stressed F344 rats were significantly higher than those in stressed LEW rats. As shown in Fig. 1B, stress significantly affected the plasma corticosterone $\left(F_{1,26}=37.08, P<0.001\right)$, and this effect depended on the strain $\left(F_{1,26}=11.77, P<0.01\right)$ and showed a stress $\times$ strain interaction $\left(F_{1,26}=12.58, P<0.01\right)$. Post hoc analysis revealed similar baseline levels of corticosterone with a significantly higher effect of stress on the plasma corticosterone in F344 rats compared to LEW rats.

\section{Effect of stress on local metabolism of glucocorticoids in lymphoid organs}

As shown in Fig. 2, exposure to stress significantly affected the 11-reductase activity of 11HSD1, in both stroma (thymus: $F_{1,21}=33.72, \quad P<0.001$; spleen: $F_{1,20}=126.58$, $P<0.001$; MLN: $\left.F_{1,20}=52.16, P<0.001\right)$ and mobile cells (thymus: $F_{1,20}=32.96, P<0.001$; spleen: $F_{1,20}=4.71, P<0.05$; MLN: $\left.F_{1,14}=53.90, \quad P<0.001\right)$, indicating stress-induced modulation of glucocorticoid regeneration in lymphoid tissues. Similarly, two-way ANOVA revealed a significant effect of the strain on 11-reductase activity in mobile cells of the thymus $\left(F_{1,20}=14.80, P<0.01\right)$, spleen $\left(F_{1,20}=5.46\right.$, $P<0.05)$ and MLN $\left(F_{1,14}=25.85, P<0.001\right)$, but no significant strain differences were found in the stroma of the three lymphoid organs. The stress $\times$ strain interactions were insignificant in all three tissues. Post hoc analysis showed a stimulatory effect of stress on the 11-reductase activity in studied lymphoid tissues of both strains, except for LEW splenocytes. In addition, a significantly higher effect of social defeat was found in thymocytes and MLN mobile cells of LEW rats than in their F344 counterparts. 11-Reductase activity in splenocytes of control unstressed LEW rats was significantly higher than that in the F344 rats and was not further upregulated in splenocytes of stressed LEW rats.

Expression of 11HSD2 measured as 11-oxidase activity was found in stroma, but it was not observed in mobile cells (Fig. 3), which agrees with previous findings of absent 11HSD2 in lymphoid cells (9). Expression of 11HSD2 in the MLN and spleen was not changed following social defeat or strain differences. In contrast, the thymic activity was influenced by stress $\left(F_{1,18}=4.43, P<0.05\right)$ and strain $\left(F_{1,18}=13.25, P<0.01\right)$, with significantly increased levels in LEW compared to F344 rats and a significant downregulation by stress (Fig. 3).

\section{Effect of stress on local metabolism of glucocorticoids in pituitary}

As release of ACTHin pituitary is controlled byglucocorticoid negative feedback (30), this gland expresses 11HSD1 (12) and ACTH and corticosterone response to stressogenic stimulus differs between F344 and LEW rats (Fig. 1), we

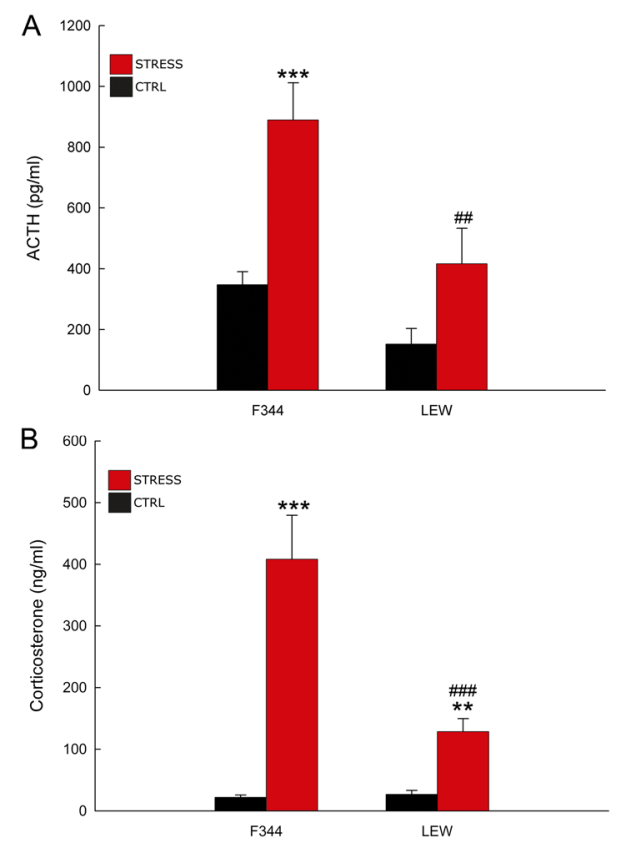

Figure 1

Plasma ACTH (A) and corticosterone (B) levels in rats exposed to repeated social defeat. The bars represent control unstressed (CTRL) and stressed rats. Data are given as the mean \pm S.E.M. Significant differences between the stressed and unstressed animals of the same strain: $* * P<0.01$ and $* * * P<0.001$ and between the F344 and LEW rats of the same treatment: ${ }^{\# \#} P<0.01$ and ${ }^{\# \#} P<0.001$.

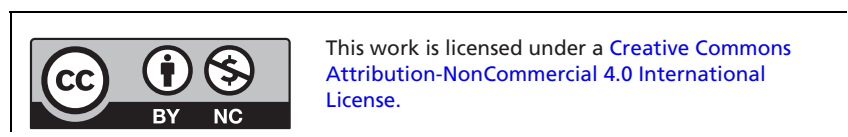



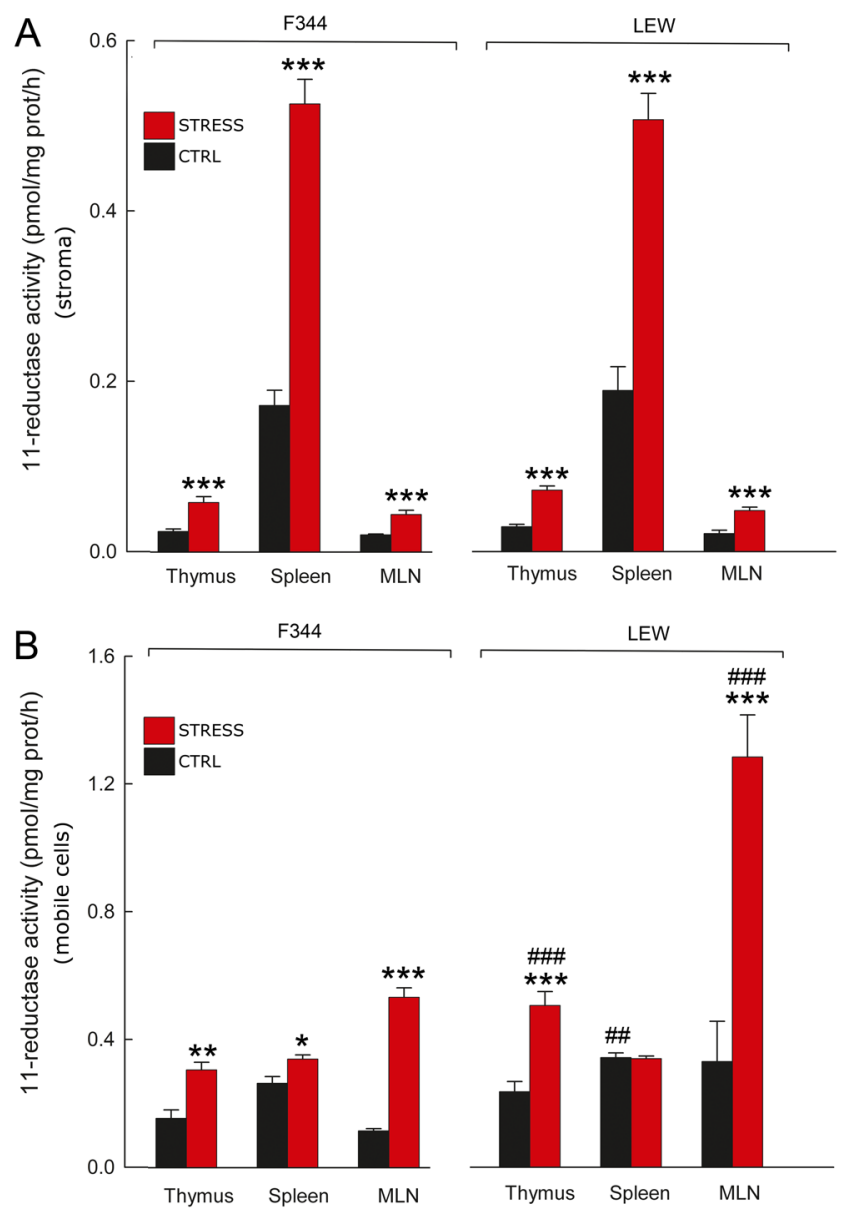

Figure 2

Effect of stress on 11-reductase activity of 11HSD1 in the stroma (A) and mobile cells (B) in lymphoid organs of control unstressed (CTLR) and stressed rats. Data are given as the mean \pm S.E.M. Significant differences between the stressed and unstressed animals of the same strain: ${ }^{*} P<0.05$, $* * P<0.01$ and $* * * P<0.001$ and between the F344 and LEW rats of the same treatment: ${ }^{\# \#} P<0.01$ and ${ }^{\# \# \#} P<0.001$.

determined whether stress results in changes of pituitary corticosterone metabolism. In contrast to lymphoid organs, pituitary tissue incubated in vitro with radioactive steroids only resulted in conversion of 11-dehydrocorticosterone to corticosterone, while oxidation of corticosterone was not detected. This finding indicates the presence of 11HSD1 but not 11HSD2 in the pituitary. As shown in Fig. 4, the 11-reductase activity of 11HSD1 was higher in F344 rats than in LEW rats $\left(F_{1,21}=12.56, P<0.01\right)$, but stress did not modulate the conversion.

\section{Discussion}

In the present study, we have characterized the consequences of social stress on glucocorticoid metabolism in the lymphoid organs and pituitary of two inbred rat

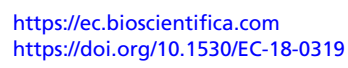

strains with differing HPA axis responsiveness. The F344 strain has been classically used as a model of HPA axis hyperactivity and hyperreactivity to stress associated with inflammation resistance, whereas the LEW strain has a hypoactive and hyporeactive HPA axis, which has been associated with vulnerability to immune diseases $(22,23)$. Consistent with previous report $(22)$, the plasma corticosterone and ACTH levels were elevated in both strains after the social defeat challenge, and the effect was greater in F344 rats. Although this result confirms the strain difference in the HPA axis, our findings demonstrate the tissue-dependent effect of stress on the local regeneration of biologically active glucocorticoids and its partial strain dependence.

Amplification of glucocorticoid metabolism in the immune system during social defeat indicates that the local effect of glucocorticoids follows both the systemic patterns of glucocorticoid synthesis by the adrenal gland and the local regeneration of corticosterone catalyzed by $11 \mathrm{HSD} 1$ via its 11-reductase activity. In contrast, the absence of any stress-dependent changes of pituitary 11-reductase activity excludes the possibility that stress might be associated with amplification of glucocorticoid signals, which are known to influence the secretion of pituitary ACTH via negative feedback (30). Considering the regulatory effects of glucocorticoids in immune cells $(19,20,21)$ and the expression of 11HSD1 in lymphocytes and immune organs $(6,8,9)$, the stress-induced upregulation of corticosterone regeneration in lymphoid organs might provide immune cells/organs with a novel

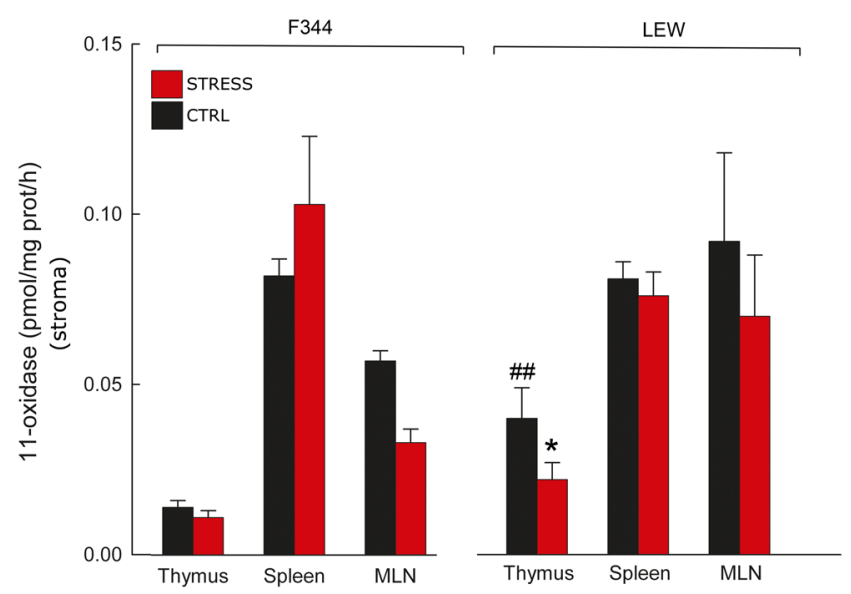

Figure 3

Effect of stress on 11-oxidase activity referring to $11 \mathrm{HSD} 2$ in the stroma of lymphoid organs of control unstressed (CTRL) and stressed rats. Data are given as the mean \pm S.E.M. Significant differences between the stressed and unstressed animals of the same strain: ${ }^{*} P<0.05$ and between the F344 and LEW rats of the same treatment: ${ }^{\#} P<0.01$.

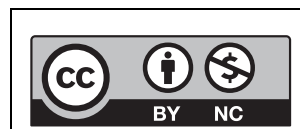

This work is licensed under a Creative Commons Attribution-NonCommercial 4.0 International License. 


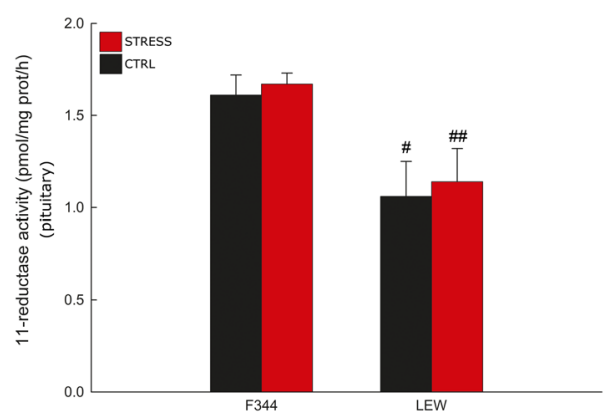

Figure 4

Strain difference in 11-reductase activity of 11HSD1 in the pituitary of F344 and LEW rats. The bars represent the mean \pm SEM of control unstressed (CTRL) and stressed rats. Significant differences between the F344 and LEW rats of the same treatment: ${ }^{\#} P<0.05$ and ${ }^{\# \# P}<0.01$.

intracrine regulatory pathway. Similar stress-induced increase of 11HSD1 was recently shown in liver (11) and murine macrophages (16), respectively.

The presence of 11-oxidase and 11-reductase activities in the stroma tissue of lymphoid organs but the absence of 11-oxidase activity in the mobile cells of lymphoid organs may reflect the presence of different subsets of cells such lymphocytes, macrophages and thymocytes in the pool of mobile cells and fibroblast, thymic epithelial cells and vascular endothelial and smooth muscle cells in the stroma. Both isoforms of 11HSDs were identified in vascular cells, whereas epithelial cells express only 11HSD2 and fibroblasts, lymphocytes, thymocytes and macrophages only $11 \mathrm{HSD} 1(5,7,9)$. In addition, it has been shown recently that thymic 11HSD2 is located at the perivascular sites of capillaries and small vessels penetrating the thymus (31) and in the thymic epithelial cells (32). Our findings are in full concordance with these data. We identified 11-reductase and 11-oxidase activities in the stroma and 11-reductase activity in the mobile cells, which indicates operational 11HSD1 and 11HSD2 in lymphoid organ stroma but 11HSD1 only in the mobile cells.

The mechanism by which social stress modulates 11HSD1 remains unknown; however, several studies have demonstrated the regulation of 11HSD1 by transcription factors of the CCAT/enhancer-binding protein $(\mathrm{C} / \mathrm{EBP})$ family $(33,34)$ and their induction by catecholamines $(35,36)$ or glucocorticoid (37). Thus, it is likely that upregulation of 11HSD1 during stress might be associated with indirect regulation via C/EBP pathway activated either by increased plasma level of corticosterone or by increased activity of catecholaminergic pathway through norepinephrine released from adrenergic terminal or through local biogenesis of catecholamines in the target tissue (38).
Consistent with previous studies, F344 rats had an exaggerated stress response compared to the LEW strain, as measured by the plasma ACTH and corticosterone, but the present data also revealed clear inter-strain differences in the local regeneration of glucocorticoids both in the pituitary and lymphoid organs, particularly in mobile cells. Compared to the F344 strain, the LEW rats exhibited a lower resting regeneration of corticosterone in the pituitary, which was insensitive to repeated social challenge. In contrast, such challenge in LEW strain was associated with an increased regeneration of corticosterone in thymocytes and MLN mobile cells and with decreased corticosterone inactivation in thymic stroma. In addition, the splenocytes from untreated LEW vs F344 rats showed an increased corticosterone regeneration, which was not further upregulated by stress. These findings suggest that the hyporesponsiveness of the HPA axis in LEW rats compared to the F344 strain (22, 23) is not associated with the LEW vs F344 difference in glucocorticoid metabolism in the pituitary. However, the well-known increased vulnerability of LEW rats to immune/inflammatory challenge (24) might be associated with a higher regeneration of corticosterone from 11-dehydrocorticosterone in thymocytes and MLN mobile cells of LEW rats exposed to stress. Considering that glucocorticoids can antagonize the signal transduction delivered through $\mathrm{T}$ cell receptors in lymphocytes $(21,39)$, differences in corticosterone regeneration might distinctly modulate the activation and survival of $\mathrm{T}$ cells in the immune organs of both strains, even if further studies will be needed to evaluate this possibility. Analogous to our findings, immune tissues of stressed LEW rats exhibit reduced glucocorticoid receptor binding compared to F344 rats, even if there are no strain differences in the total glucocorticoid receptor levels in most immune tissues (22).

In summary, our findings indicate that social stress increases the local glucocorticoid production in lymphoid organs via corticosterone regeneration from a biologically inactive 11-oxo derivative, 11-dehydrocorticosterone, and this regeneration partially depends on the strain. As the stress-dependent increase of glucocorticoid production in mobile lymphoid organ cells is higher in LEW than in F344 rats, it is reasonable to assume that these straindependent differences might participate in the higher susceptibility of the LEW strain to inflammatory diseases.

\section{Supplementary data}

This is linked to the online version of the paper at https://doi.org/10.1530/ EC-18-0319. 


\section{Declaration of interest}

The authors declare that there is no conflict of interest that could be perceived as prejudicing the impartiality of the research reported.

\section{Funding}

This study was financially supported by the Czech Science Foundation (grants 15-07268S and 18-02993S).

\section{Acknowledgements}

The authors are grateful to Ivana Muricová for the technical assistance.

\section{References}

1 McEwen BS, Biron CA, Brunson KW, Bulloch K, Chambers WH, Dhabhar FS, Goldfarb RH, Kitson RP, Miller AH, Spencer RL, et al. The role of adrenocorticoids as modulators of immune function in health and disease: neural, endocrine and immune interactions. Brain Research Reviews 199723 79-133. (https://doi.org/10.1016/S01650173(96)00012-4)

2 Cohen S, Janicki-Deverts D, Doyle WJ, Miller GE, Frank E, Rabin BS $\&$ Turner RB. Chronic stress, glucocorticoid receptor resistance, inflammation, and disease risk. PNAS 2012109 5995-5999. (https:// doi.org/10.1073/pnas.1118355109)

3 Silverman MN \& Sternberg EM. Glucocorticoid regulation of inflammation and its functional correlates: from HPA axis to glucocorticoid receptor dysfunction. Annals of the New York Academy of Sciences 20121261 55-63. (https://doi.org/10.1111/ j.1749-6632.2012.06633.x)

4 Bowers SL, Bilbo SD, Dhabhar FS \& Nelson RJ. Stressor-specific alterations in corticosterone and immune responses in mice. Brain Behavior and Immunity 200822 105-113. (https://doi.org/10.1016/j. bbi.2007.07.012)

5 Chapman K, Holmes M \& Seckl J. 11 $\beta$-Hydroxysteroid dehydrogenases: intracellular gate-keepers of tissue glucocorticoid action. Physiological Reviews 201393 1139-1206. (https://doi. org/10.1152/physrev.00020.2012)

6 Ergang P, Vytáčková K, Švec J, Bryndová J, Mikšík I \& Pácha J. Upregulation of 11 $\beta$-hydroxysteroid dehydrogenase 1 in lymphoid organs during inflammation in the rat. Journal of Steroid Biochemistry and Molecular Biology 2011126 19-25. (https://doi.org/10.1016/j. jsbmb.2011.04.002)

7 Nuotio-Antar AM, Hasty AH \& Kovacs WJ. Quantitation and cellular localization of $11 \beta$-HSD1 expression in murine thymus. Journal of Steroid Biochemistry and Molecular Biology 200699 93-99. (https://doi. org/10.1016/j.jsbmb.2006.01.011)

8 Taves MD, Plumb AW, Korol AM, Van Der Gugten JG, Holmes DT, Abraham N \& Soma KK. Lymphoid organs of neonatal and adult mice preferentially produce active glucocorticoids from metabolites, not precursors. Brain Behavior and Immunity 201657 271-281. (https://doi.org/10.1016/j.bbi.2016.05.003)

9 Zhang TY, Ding X \& Daynes RA. The expression of 11 $\beta$-hydroxysteroid dehydrogenase type I by lymphocytes provides a novel means for intracrine regulation of glucocorticoid activities. Journal of Immunology 2005174 879-889. (https://doi.org/10.4049/jimmunol.174.2.879)

10 Hennebold JD, Ryu SY, Mu HH, Galbraith A \& Daynes RA. $11 \beta$-Hydroxysteroid dehydrogenase modulation of glucocorticoid activities in lymphoid organs. American Journal of Physiology: Regulatory, Integrative and Comparative Physiology 1996270 R1296-R1306. (https://doi.org/10.1152/ajpregu.1996.270.6.R1296)

11 Corona-Pérez A, Díaz-Muñoz M, Rodríguez IS, Cuevas E, MartínezGómez M, Castelán F, Rodríguez-Antolín J \& Nicolás-Toledo L.
High sucrose intake ameliorates the accumulation of hepatic triacylglycerol promoted by restraint stress in young rats. Lipids 2015 50 1103-1113.

12 Ergang P, Vodička M, Soták M, Klusoňová P, Behuliak M, Řeháková L, Zach P \& Pácha J. Differential impact of stress on hypothalamicpituitary-adrenal axis: gene expression changes in Lewis and Fisher rats. Psychoneuroendocrinology 201553 49-59. (https://doi. org/10.1016/j.psyneuen.2014.12.013)

13 Jamieson PM, Fuchs E, Flugge G \& Seckl JR. Attenuation of hippocampal 11ß-hydroxysteroid dehydrogenase type 1 by chronic psychosocial stress in the tree shrew. Stress 19972 123-132. (https:// doi.org/10.3109/10253899709014743)

14 Jellinck PH, Dhabhar FS, Sakai RR \& McEwen BS. Longterm corticosteroid treatment but not chronic stress affects $11 \beta$-hydroxysteroid dehydrogenase type I activity in rat brain and peripheral tissues. Journal of Steroid Biochemistry and Molecular Biology 199760 319-323. (https://doi.org/10.1016/S0960-0760(96) 00197-5)

15 Monder C, Sakai RR, Miroff Y, Blanchard DC \& Blanchard RJ. Reciprocal changes in plasma corticosterone and testosterone in stressed male rats maintained in a visible burrow system: evidence for a mediating role of testicular 11 $\beta$-hydroxysteroid dehydrogenase. Endocrinology 1994134 1193-1198. (https://doi.org/10.1210/ endo.134.3.8119159)

16 Sesti-Costa R, Ignacchiti MD, Chedraoui-Silva S, Marchi LF \& Mantovani B. Chronic cold stress in mice induces a regulatory phenotype in macrophages: correlation with increased 11ß-hydroxysteroid dehydrogenase expression. Brain Behavior and Immunity 201226 50-60. (https://doi.org/10.1016/j.bbi.2011.07.234)

17 Reber SO, Peters S, Slattery DA, Hofmann C, Schölmerich J, Neumann ID \& Obermeier F. Mucosal immunosuppression and epithelial barrier defects are key events in murine psychosocial stressinduced colitis. Brain Behavior and Immunity 201125 1153-1161. (https://doi.org/10.1016/j.bbi.2011.03.004)

18 Cohen S, Janicki-Deverts D \& Miller GE. Psychological stress and disease. JAMA 2007298 1685-1687. (https://doi.org/10.1001/ jama.298.14.1685)

19 Ashwell JD, Lu FW \& Vacchio MS. Glucocorticoids in T cell development and function. Annul Review of Immunology $2000 \mathbf{1 8}$ 309-345. (https://doi.org/10.1146/annurev.immunol.18.1.309)

20 Tuckermann JP, Kleiman A, Moriggl R, Spanbroek R, Neumann A, Illing A, Clausen BE, Stride B, Förster I \& Habenicht AJ, et al. Macrophages and neutrophils are the targets for immune suppression by glucocorticoids in contact allergy. Journal of Clinical Investigation 2007117 1381-1390. (https://doi.org/10.1172/JCI28034)

21 Mittelstadt PR, Monteiro JP \& Ashwell JD. Thymocyte responsiveness to endogenous glucocorticoids is required for immunological fitness. Journal of Clinical Investigation 2012122 2384-2394. (https://doi. org/10.1172/JCI63067)

22 Dhabhar FS, Miller AH, McEwen BS \& Spencer RL. Differential activation of adrenal steroid receptors in neural and immune tissues of Sprague Dawley, Fischer 344, and Lewis rats. Journal of Neuroimmunology 199556 77-90. (https://doi.org/10.1016/01655728(94)00135-B)

23 Dhabhar FS, McEwen BS \& Spencer RL. Adaptation to prolonged or repeated stress - comparison between rat strains showing intrinsic differences in reactivity to acute stress. Neuroendocrinology 199765 360-368. (https://doi.org/10.1159/000127196)

24 Sternberg EM, Hill JM, Chrousos GP, Kamilaris T, Listwak SJ, Gold PW \& Wilder RL. Inflammatory mediator-induced hypothalamicpituitary-adrenal axis activation is defective in streptococcal cell wall arthritis-susceptible Lewis rats. PNAS 198986 2374-2378. (https:// doi.org/10.1073/pnas.86.7.2374)

25 Chaouloff F. Social stress models in depression research: what do they tell us? Cell and Tissue Research 2013354 179-190. (https://doi. org/10.1007/s00441-013-1606-x)
This work is licensed under a Creative Commons Attribution-NonCommercial 4.0 International License. 
26 Buwalda B, Kole MH, Veenema AH, Huininga M, de Boer SF, Korte SM \& Koolhaas JM. Long-term effects of social stress on brain and behavior: a focus on hippocampal functioning. Neuroscience and Biobehavioral Reviews 200529 83-97. (https://doi.org/10.1016/j. neubiorev.2004.05.005)

27 Haller J, Fuchs E, Halász J \& Makara GB. Defeat is a major stressor in males while social instability is stressful mainly in females: towards the development of a social stress model in female rats. Brain Research Bulletin 199950 33-39. (https://doi.org/10.1016/S03619230(99)00087-8)

28 Pácha J, Mikšík I, Lisá V \& Pohlová I. Hormonal regulation of intestinal 11ß-hydroxysteroid dehydrogenase. Life Sciences 199761 2391-2396. (https://doi.org/10.1016/S0024-3205(97)00956-9)

29 Pácha J, Mikšík I, Mrnka L, Zemanová Z, Bryndová J, Mazancová K \& Kučka M. Corticosteroid regulation of colonic ion transport during postnatal development: methods for corticosteroid analysis. Physiological Research 200453 S63-S80.

30 Keller-Wood M. Hypothalamic-pituitary-adrenal axis-feedback control. Comprehensive Physiology 201553 1161-1182. (https://doi. org/10.1002/cphy.c140065)

31 Almanzar G, Mayerl C, Seitz JC, Höfner K, Brunner A, Wild V, Jahn D, Geier A, Fassnacht M \& Prelog M. Expression of 11 $\beta$-hydroxysteroiddehydrogenase type 2 in human thymus. Steroids $201611035-40$ (https://doi.org/10.1016/j.steroids.2016.03.019)

32 Qiao S, Chen L, Okret S \& Jondal M. Age-related synthesis of glucocorticoids in thymocytes. Experimental Cell Research $2008 \mathbf{3 1 4}$ 3027-3035. (https://doi.org/10.1016/j.yexcr.2008.06.014)

33 Esteves CL, Kelly V, Breton A, Taylor AI, West CC, Donadeu FX, Péault B, Seckl JR \& Chapman KE. Proinflammatory cytokine induction of $11 \beta$-hydroxysteroid dehydrogenase type 1 (11 $\beta$-HSD1) in human adipocytes is mediated by MEK, C/EBP $\beta$, and NF-кB/RelA. Journal of Clinical Endocrinology and Metabolism 201499 E160-E168. (https://doi.org/10.1210/jc.2013-1708)
34 Ignatova ID, Kostadinova RM, Goldring CE, Nawrocki AR, Frey FJ $\&$ Frey BM. Tumor necrosis factor- $\alpha$ upregulates $11 \beta$-hydroxysteroid dehydrogenase type 1 expression by CCAAT/enhancer binding protein- $\beta$ in HepG 2 cells. American Journal of Physiology: Endocrinology and Metabolism 2009296 E367-E377. (https://doi.org/10.1152/ ajpendo.90531.2008)

35 Briest W, Rassler B, Deten A, Leicht M, Morwinski R, Neichel D, Wallukat G, Ziegelhöffer T \& Zimmer HG. Norepinephrine-induced interleukin-6 increase in rat hearts: differential signal transduction in myocytes and non-myocytes. Pflügers Archiv: Europen Journal of Physiology 2003446 437-446. (https://doi.org/10.1007/s00424003-1043-x)

36 Cardinaux JR \& Magistretti PJ. Vasoactive intestinal peptide, pituitary adenylate cyclase-activating peptide, and noradrenaline induce the transcription factors CCAAT/enhancer binding protein (C/EBP)- $\beta$ and C/EBP- $\delta$ in mouse cortical astrocytes: involvement in cAMP-regulated glycogen metabolism. Journal of Neuroscience 199616 919-929. (https://doi.org/10.1523/ JNEUROSCI.16-03-00919.1996)

37 Sai S, Esteves CL, Kelly V, Michailidou Z, Anderson K, Coll AP, Nakagawa Y, Ohzeki T, Seckl JR \& Chapman KE. Glucocorticoid regulation of the promoter of $11 \beta$-hydroxysteroid dehydrogenase type 1 is indirect and requires CCAAT/enhancer-binding protein- $\beta$. Molecular Endocrinology 200822 2049-2060. (https://doi.org/10.1210/ me.2007-0489)

38 Laukova M, Vargovic P, Vlcek M, Lejavova K, Hudecova S, Krizanova $\mathrm{O} \&$ Kvetnansky R. Catecholamine production is differently regulated in splenic T- and B-cells following stress exposure. Immunobiology 2013218 780-789. (https://doi. org/10.1016/j.imbio.2012.08.279)

39 Jondal M, Pazirandeh A \& Okret S. Different roles for glucocorticoids in thymocyte homeostasis? Trends in Immunology 200425 595-600. (https://doi.org/10.1016/j.it.2004.09.003)

Received in final form 25 October 2018

Accepted 30 October 2018

Accepted Preprint published online 1 November 2018

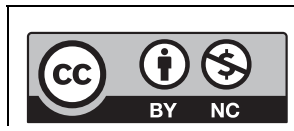

This work is licensed under a Creative Commons Attribution-NonCommercial 4.0 International License. 